Pflügers Arch (1994) 428:261-268

\title{
Endothelium derived relaxing factor is involved in the pressure control of renin gene expression in the kidney
}

\author{
Karin Schricker, Roberto Della Bruna, Marlies Hamann, Armin Kurtz \\ Institut für Physiologie I, Universität Regensburg, Postfach 101042, D 93040 Regensburg, Germany
}

Received February 10, 1994/Received after revision April 21, 1994/Accepted April 22, 1994

\begin{abstract}
To study the influence of endothelium derived relaxing factor/nitric oxide (EDNO) on renin gene expression, the effects of a 2-day treatment with the NOsynthase inhibitor nitro-L-arginine-methylester (LNAME, $40 \mathrm{mg} / \mathrm{kg}$ twice a day) on plasma renin activity (PRA) and renal and adrenal renin m-RNA levels were examined in conscious rats with and without unilateral renal clips $(0.2 \mathrm{~mm})$. In sham-clipped animals L-NAME led to a decrease of PRA from 7.5 to $2.5 \mathrm{ng}$ angiotensin I (ANGI) $\cdot \mathrm{h}^{-1} \cdot \mathrm{ml}^{-1}$ and to a $35 \%$ decrease of renal renin $\mathrm{m}$-RNA levels. Unilateral renal artery clipping increased PRA to 35 and to $13 \mathrm{ng}$ ANGI $\cdot \mathrm{h}^{-1} \cdot \mathrm{ml}^{-1}$ in vehicle and in L-NAME-treated rats, respectively. In the clipped kidneys renin m-RNA levels increased to $450 \%$ of control values in vehicle-treated animals and to $220 \%$ of control values in L-NAME-treated animals. In the contralaterals as opposed to clipped kidneys, renin m-RNA levels decreased to $16 \%$ and $50 \%$ of the control values in vehicle- and in L-NAME-treated animals, respectively. In the adrenal glands renin m-RNA levels were not significantly changed either by clipping of one renal artery or by treatment of animals with L-NAME. The NO-donor sodium nitroprusside $(100 \mu \mathrm{M})$ was found to increase renin secretion and renin m-RNA levels in primary cultures of renal juxtaglomerular cells. These findings suggest that EDNO is involved in the control of the renin gene by the renal perfusion pressure.
\end{abstract}

Key words: Juxtaglomerular cells - EDRF - RAAS

\section{Introduction}

There is accumulating evidence that endothelium derived relaxing factor (EDRF), which is considered to be nitric oxide (NO), is a potent modulator of renin secre-

Correspondence to: $\mathrm{K}$. Schricker tion from the kidneys $[1,8,11,15,16,18,23,24,27]$. A potential physiological role of EDRF/NO (or EDNO) in the control of renin secretion is, moreover, suggested by the high level expression of NO-synthase in renal macula densa cells $[14,26,28]$, which are directly adjacent to juxtaglomerular (JG) cells which produce, store and release renin in a regulated fashion [9]. The precise effect of EDNO on renin secretion, however, is still a matter of controversy. Thus, there are on the one hand reports of data obtained with anaesthetized rats [24] and with renal slices $[1,27]$ suggesting that EDNO exerts an inhibitory effect on renin secretion. There are on the other hand findings obtained from conscious [18] and anaesthetized dogs [16], isolated perfused rat kidneys [8, 15,23 ] and from isolated renal JG cells [11] suggesting that EDNO is a potent stimulator of renin secretion. The studies with the dogs and the isolated rat kidneys, moreover, strongly suggest that EDNO is essentially involved in the enhancement of renin secretion in response to a fall in renal artery pressure, a phenomenon that is commonly referred to as to the "baroreceptor-control" of renin secretion.

Although the linkage between renin secretion, renin synthesis and renin gene expression on the level of JG cells is not well understood, there is evidence for a concordant control of renin secretion and renin m-RNA levels by renal perfusion pressure [13]. In view of the profound effects of EDNO on pressure-related renin secretion it appeared reasonable, therefore, to also consider a potential role of EDNO on renin gene expression in this context.

We have addressed this question by examining the effect of the NO-synthase inhibitor nitro-L-arginine methylester (L-NAME) on renin m-RNA levels in conscious rats with and without unilateral renal artery stenosis.

Our findings strongly suggest that EDNO is an activator of renin gene expression in the kidney and is involved in the baroreceptor-control of renin gene expression. 


\section{Materials and methods}

Animals. Male Sprague Dawley rats weighing $180-220 \mathrm{~g}$ were used for the experiments. Animals had free access to normal food (Altromin) and tap water.

Time course of renal renin $m-R N A$ levels after unilateral renal artery clipping. A total of 16 animals were anaesthetized with methohexital $(50 \mathrm{mg} / \mathrm{kg}$ ) and the left kidney was exposed by an abdominal incision. Sterile silver clips (Degussa, Germany) with an inner diameter of $0.2 \mathrm{~mm}$ were then placed on the left renal arteries. After 1, 2, 5 and 10 days four rats each were killed by decapitation and kidneys were rapidly removed. Kidneys were weighed, cut in half and frozen in liquid nitrogen until extraction of total RNA for determination of preprorenin m-RNA.

L-NAME treatment of clipped and sham-clipped rats. A total of 24 animals were anaesthetized with methohexital $(50 \mathrm{mg} / \mathrm{kg})$ and the left kidney was exposed by an abdominal incision. In 12 animals sterile silver clips (Degussa) with an inner diameter of $0.2 \mathrm{~mm}$ were then placed on the left renal arteries. In 12 sham-clipped animals the left artery was touched only with forceps. The animals were awakened within $30 \mathrm{~min}$ after the operation and the NOsynthase inhibitor L-NAME $(40 \mathrm{mg} / \mathrm{kg})$ or vehicle $(0.9 \% \mathrm{NaCl})$ were applied by intraperitoneal injection, to achieve protracted action of the drug. For replacement of eliminated drug the injections of drugs were repeated at 12 -h intervals during experiments. During this period systolic blood pressure and heart rate were determined with a BP recorder 8005 (Rhema, Hofheim, Germany) in the morning ( $2 \mathrm{~h}$ after previous application of drugs) and in the afternoon ( $8 \mathrm{~h}$ after previous application of drugs). Then, $48 \mathrm{~h}$ after operation the animals were killed by decapitation. Blood was collected from the carotid arteries for determination of PRA and both kidneys and adrenal glands were rapidly removed, kidneys weighed, cut in half and frozen in liquid nitrogen until extraction of total RNA for determination of preprorenin m-RNA.

Determination of preprorenin $m-R N A$. Total RNA was extracted from the kidneys which were stored at $-70^{\circ} \mathrm{C}$, according to the protocol of Chomczynski [3] by homogenization in $10 \mathrm{ml}$ of solution $\mathrm{D}$ [guanidine thiocyanate $(4 \mathrm{M})$ containing $0.5 \% \mathrm{~N}$-laurylsarcosinate, $10 \mathrm{mM}$ EDTA, $25 \mathrm{mM}$ sodium citrate and $700 \mathrm{mM} \beta$ mercaptoethanol] with a polytron homogenizer. Sequentially, $1 \mathrm{ml}$ of $2 \mathrm{M}$ sodium acetate ( $\mathrm{pH} \mathrm{4}$ ), $10 \mathrm{ml}$ phenol (water saturated) and $2 \mathrm{ml}$ chloroform were added to the homogenate, with thorough mixing after addition of each reagent. After cooling on ice for 15 min samples were centrifuged at $10,000 \mathrm{~g}$ for $15 \mathrm{~min}$ at $4^{\circ} \mathrm{C}$. RNA in the supernatant was precipitated with an equal volume of isopropanol at $-20^{\circ} \mathrm{C}$ for at least $1 \mathrm{~h}$. After centrigugation RNA pellets were resuspended in $0.5 \mathrm{ml}$ of solution $\mathrm{D}$, again precipitated with an equal volume of isopropanol at $-20^{\circ} \mathrm{C}$ and RNA pellets were finally dissolved in diethylpyrocarbonate-treated water and stored at $-80^{\circ} \mathrm{C}$ till further processing. Renin m-RNA was measured by RNase protection as described for erythropoietin [21]. A preprorenin cRNA-probe containing 296 base pairs (bp) of exon I and II, generated from a pGEM-4 vector carrying a PstI-KpnI restriction fragment of a rat preprorenin cDNA [2], was generated by transcription with SP6 RNA polymerase (Amersham International, Amersham, UK). Transcripts were continuously labelled with $\left[\alpha^{32}\right.$ P]GTP ( $410 \mathrm{Ci} / \mathrm{mmol}$; Amersham) and purified on a Sephadex G50 spun column. For hybridization total kidney RNA was dissolved in a buffer containing $80 \%$ formamide, $40 \mathrm{mM}$ piperazine $N, N^{\prime}$-bis(2-ethane sulphonic acid), $400 \mathrm{mM} \mathrm{NaCl}, 1 \mathrm{mM}$ EDTA (pH 8). RNA $(20 \mu \mathrm{g})$ was hybridized in a total volume of $50 \mu \mathrm{l}$ at $60^{\circ} \mathrm{C}$ for $12 \mathrm{~h}$ with $8.3 \times 10^{3} \mathrm{~Bq}$ radiolabelled renin probe. RNase digestion with RNase $\mathrm{A}$ and $\mathrm{T} 1$ was carried out at $20^{\circ} \mathrm{C}$ for $30 \mathrm{~min}$ and terminated by incubation with proteinase $\mathrm{K}(0.1 \mathrm{mg} /$ $\mathrm{ml}$ ) and sodium dodecyl sulphate (SDS, $0.4 \%$ ) at $37^{\circ} \mathrm{C}$ for 30 min.

Protected preprorenin m-RNA fragments were purified by phenol/chloroform extraction, ethanol precipitation and subsequent

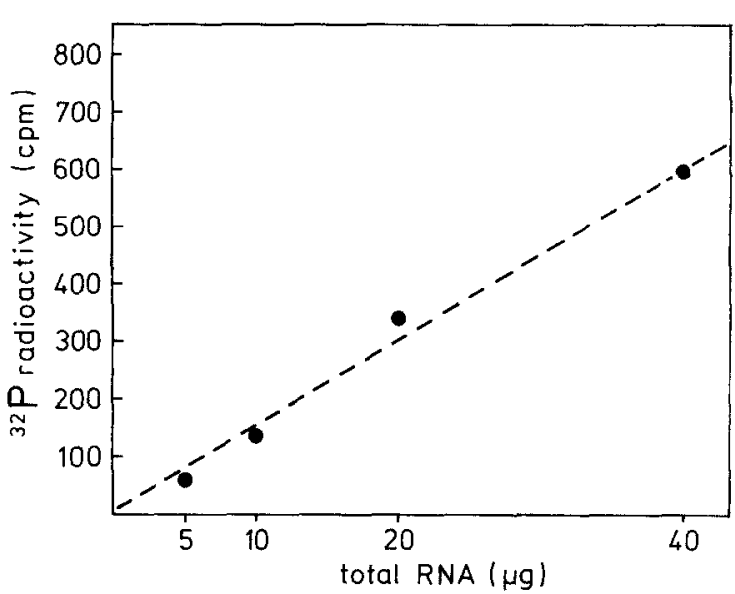

Fig. 1. Radioactivity counted in excised bands of acrylamid gel after autoradiography of RNase protection assay for renin m-RNA using different amounts of renal RNA standard

electrophoresis on a denaturing $10 \%$ polyacrylamide gel. After autoradiography of the dried gel at $-70^{\circ} \mathrm{C}$ for $1-2$ days, bands representing protected renin $\mathrm{m}-\mathrm{RNA}$ fragments were excised from the gel and radioactivity was counted with a liquid scintillation counter (1500 Tri-CarbTm, Packard Instrument Company, Downers Grove, 111., USA). The number of counts per minute obtained from each sample of total kidney RNA was expressed relative to an external renin m-RNA standard included in each hybridization consisting of $20 \mu \mathrm{g}$ pooled RNA extracted from the 12 kidneys of 6 normal Sprague Dawley rats. Figure 1 shows the results of an RNase protection assay for renin m-RNA using different amounts of the pooled RNA used as standard.

Determination of actin $m-R N A$. The abundance of rat cytoplasmatic $\beta$-actin $\mathrm{m}$-RNA in total RNA isolated from the kidneys was determined by an RNase protection assay exactly as described for preprorenin. An actin cRNA-probe containing the 76 nucleotide first exon and around $200 \mathrm{bp}$ of the surrounding sequence was generated by transcription with SP6 polymerase from a pAM19 vector carrying an Aval/HindIII restriction fragment of actin cDNA [21]. For one assay $2.5 \mu \mathrm{g}$ RNA was hybridized under the conditions described for the determination of renin m-RNA.

Densitometry of preprorenin $m$-RNA of adrenal glands. Levels of preprorenin m-RNA in adrenal glands were estimated by densitometry (elscript 400, Hirschmann, Unterhaching, Germany) of the autoradiographs, which were exposed for $2-3$ weeks. On each gel 2 renin m-RNA standards, consisting of 2 and $0.5 \mu \mathrm{g}$ pooled RNA extracted from 12 kidneys of 6 normal Sprague Dawley rats, were coanalysed and densitometric values related to the standard of $2 \mu \mathrm{g}$ total RNA (Fig. 7).

Determination of PRA. PRA was determined utilizing a commercially available radioimmunoassay kit for angiotensin I (ANGI) (Sorin Biomedica, Düsseldorf, Germany).

Experiments with primary cultures of mouse renal juxtaglomerular $(J G)$ cells. JG cells were isolated as previously described [4] from the mouse strain C57B16, which expresses only the ren-1 gene. The isolated cells were cultured in 96-well plates exactly as described [4]. The cultures were incubated at $37^{\circ} \mathrm{C}$ in a humidified atmosphere containing $5 \% \mathrm{CO}_{2}$ in air. Experiments were performed after $20 \mathrm{~h}$ of primary culture. At this time the culture medium was removed and the cultures were washed once with culture medium. Fresh culture medium together with the drugs to be tested or their respective solvent controls were then added.

Determination of renin secretion. At the end of the experiments, supernatants were collected and centrifuged at $500-1,000 \mathrm{~g}$ at 
room temperature to remove cellular debris. The supernatants were then stored at $-20^{\circ} \mathrm{C}$ for further processing. Cells were lysed by adding to each culture well $50 \mu \mathrm{l}$ of phosphate-buffered saline (PBS) containing $0.1 \%$ Triton X-100, and then shaking for $45 \mathrm{~min}$ at room temperature. The lysed cells were stored at $-20^{\circ} \mathrm{C}$ for further processing.

Renin secretion rates were estimated from the appearance rate of renin activity in the culture medium. To minimize differences among different cell culture preparations, renin secretion rates were calculated as fractional release of total renin [i.e. renin activity released/(renin activity released + renin activity remaining in the cells)]. Renin activity was determined by its ability to generate ANGI from the plasma of bilaterally nephrectomized rats. ANGI was measured by radioimmunoassay (Sorin Biomedica).

Determination of renin $m$-RNA in the cultured cells. At the end of the incubation experiments, cultured cells were placed on ice, the culture medium was removed and the cells were washed once with ice-cold PBS buffer. Then, the cells were lysed by adding 40 an ice-cold buffer containing $2 \%$ Nonidet (NP 40), $10 \mathrm{mM}$ Tris$\mathrm{HCl}(\mathrm{pH} 8), 10 \mathrm{mM} \mathrm{NaCl}, 3 \mathrm{mM} \mathrm{MgCl}$ and $0.7 \%$ (vol/vol) mercaptoethanol to each culture well and shaking for $15 \mathrm{~min}$ at $4^{\circ} \mathrm{C}$. The cellular lysates of two culture wells were pooled for the determination of renin m-RNA. Cell nuclei were removed by centrifugation at $12,000 \mathrm{~g}$ and $4^{\circ} \mathrm{C}$ for $3 \mathrm{~min}$. Of the cytoplasmic fraction $3 \mu \mathrm{l}$ was immediately used for reverse transcription, the remaining part was stored at $-20^{\circ} \mathrm{C}$ for cellular protein measurement.

Renin $\mathrm{m}$-RNA was measured using a reverse transcriptasepolymerase chain reaction method (RT-PCR) exactly as described recently [5]. In brief, a sense primer which spans the exon 6/exon 7 border of the renin gene, and antisense primer located on exon 8 were used, thus amplifying a 194-bp sequence. For quantification, an internal renin m-RNA standard $(254 \mathrm{bp}$ ) was synthesized by inserting a 60 -bp fragment into the normal renin m-RNA sequence amplified by the RT-PCR exactly as described [5].

Reverse transcriptase reaction. A 10- $\mu \mathrm{l}$ aliquot of an ice-cold solution containing $10 \mathrm{pmol}$ of the antisense primer, $1 \mu \mathrm{g}$ of yeast tRNA and $5 \mathrm{pg}$ of the internal standard were added to $3 \mu \mathrm{l}$ of the cytosolic fraction. Samples were heated $5 \mathrm{~min}$ at $94^{\circ} \mathrm{C}$ and then chilled on ice. Then, $10 \mu \mathrm{l}$ of solution A were added and the samples incubated at $37^{\circ} \mathrm{C}$ for $1 \mathrm{~h}$. Solution A consisted of $22 \mu \mathrm{l}$ of a $25 \mathrm{mM}$ solution of desoxyribonucleotides, $45 \mu 1$ of $5 \times$ RT-buffer (supplied with the reverse transcriptase kit), $6 \mu 1$ of the RNase inhibitor rRNasin (Promega), $9 \mu \mathrm{l}$ of M-MLV Reverse transcriptase (Gibco-Brl) and $20 \mu \mathrm{l}$ of $0.1 \mathrm{M}$ dithiothreitol. After incubation at $37^{\circ} \mathrm{C}$ for $1 \mathrm{~h}$, the reaction was stopped by heating the samples for $2 \min$ at $95^{\circ} \mathrm{C}$.

Polymerase chain reaction. To $3 \mu 1$ of the cDNA solution, $2.5 \mu \mathrm{l}$ of $10 \times$ PCR-buffer (supplied with Taq polymerase), $1 \mu \mathrm{l}$ (10 pmol) of each primer, $4.5 \mu \mathrm{l}$ of a $25 \mathrm{mM} \mathrm{MgCl}_{2}$ solution, $14 \mu \mathrm{l}$ $\mathrm{H}_{2} \mathrm{O}$ and $5 \mu \mathrm{Ci}$ of $\left[{ }^{3} \mathrm{H}\right] \mathrm{dCTP}$ were added: samples were overlayered with mineral oil, denatured at $94^{\circ} \mathrm{C}$ for $5 \mathrm{~min}$ and cooled to $65^{\circ} \mathrm{C}$ for $5 \mathrm{~min}$. After addition of $1 \mu \mathrm{l}$ of $25 \mathrm{mM}$ desoxyribonucleotide solution and 1.25 units of Taq polymerase (Boehringer Mannheim, Germany), 30 PCR cycles consisting of denaturation at $94^{\circ} \mathrm{C}(1 \mathrm{~min})$, annealing at $60^{\circ} \mathrm{C}(1 \mathrm{~min})$ and extension at $72^{\circ} \mathrm{C}(30 \mathrm{~s})$ were performed. PCR was completed by a final extension step of $10 \mathrm{~min}$ at $72^{\circ} \mathrm{C}$. After PCR, the amplification products originating from renin mRNA or from the internal standard were separated by polyacrylamide gel electrophoresis. $N, N^{\prime}$-Methylenebis-acrylamide was replaced by dihydroxyethylene-bis-acrylamide. The bands were excised, solubilized in $0.025 \mathrm{M}$ periodic acid and radioactivity assessed in a $\beta$-counter. The radioactivity incorporated by renin mRNA was routinely related as a percentage to the radioactivity incorporated by the $5 \mathrm{pg}$ of internal standard.

Statistics. ANOVA $t$-test was used for interindividual comparisons and student's paired $t$-test for intraindividual comparisons. $P<0.05$ was considered significant.

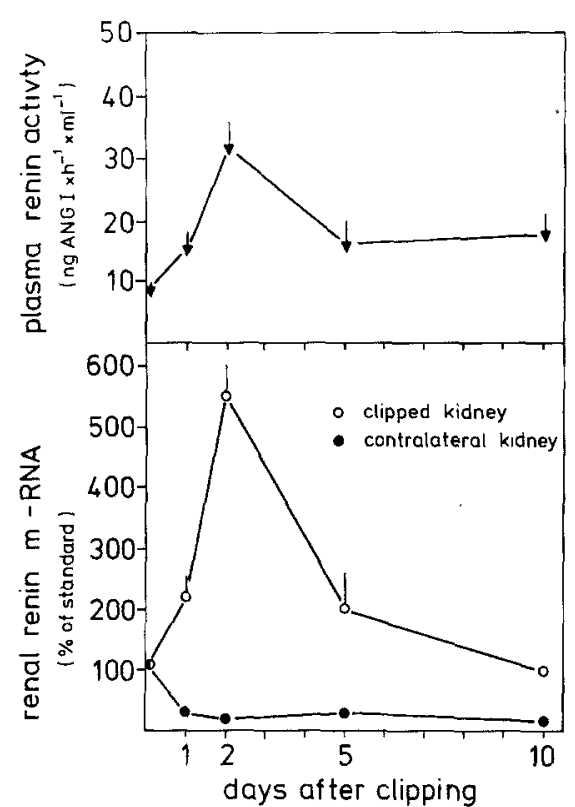

Fig. 2. Time course of plasma renin activity (PRA, upper panel) and renin m-RNA levels (lower panel) in clipped and contralateral - kidneys ( $0.2 \mathrm{~mm}$ clip). Renin m-RNA levels are expressed in relation to an external standard. Data are means \pm SEM of 4 animals at each time point

\section{Results}

Renin gene expression was studied in male Sprague Dawley rats with either normal renal blood flow, or with unilateral reduction of blood flow induced by silver clips with an inner diameter of $0.2 \mathrm{~mm}$. To find the time point of maximal stimulations of renal renin gene expression and renin secretion we first measured renin m-RNA levels in the stenosed and in the contralateral kidneys, as well as PRA levels 1, 2, 5 and 10 days after setting the clips. As shown in Fig. 2, the unilateral reduction of renal blood flow caused an increase of renin m-RNA levels of the clipped kidneys, which reached a maximum (550\% of basal level) 2 days after setting the clip and returned to control values within 10 days (Fig. 2). In contralateral kidneys renin m-RNA levels were suppressed to about $30 \%$ of control values after 1 day and this reduction of renin m-RNA remained throughout the 10 days of the experiments (Fig. 2). PRA levels paralleled the $m$-RNA levels in the stenosed kidneys. For further experiments studying the influence of EDNO we chose, therefore, a time interval of $48 \mathrm{~h}$ after setting the clips, when PRA levels and renin m-RNA levels in the clipped kidneys were maximally stimulated, while renin m-RNA levels in the contralateral kidneys were significantly suppressed.

To inhibit endogenous EDNO formation we used intraperitoneal injections of L-NAME $(40 \mathrm{mg} / \mathrm{kg}$ twice a day) which has been found to be a tolerable inhibitor of NO-synthase in vivo [22]. To assess possible side effects of EDNO inhibition with relevance for the control of the renin system, such as an increase of blood pressure [22] or reflex inhibition of sympathetic outflow, we measured arterial pressure and heart rates during the 2 days of 


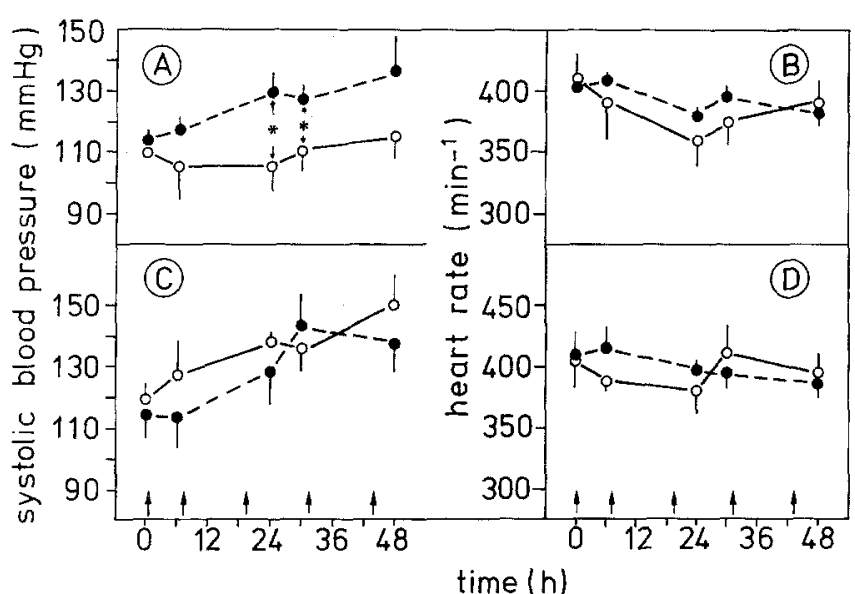

Fig. 3. Systolic blood pressure of sham-clipped rats (A) and rats with left renal artery clip (C) and heart rate of sham-clipped rats (B) and rats with left renal artery clip (D) after vehicle (open symbols) and nitro-L-arginine-methylester (L-NAME) (closed symbols) treatment. Data are means \pm SEM of 6 animals in each experimental group. Injection of L-NAME $(40 \mathrm{mg} / \mathrm{kg})$ is indicated by arrows). * $P<0.05$

treatment with L-NAME. As shown in Fig. 3, L-NAME caused a significant increase of systolic blood pressure, but had no measurable effect on heart rate in animals with nonclipped kidneys. Clipping of one renal artery did not change heart rates, but led to an increase of systolic blood pressure in vehicle-injected animals (Fig. 3). Again L-NAME did not change heart rates in this group of rats whilst the increase of blood pressure upon clipping of one renal artery was the same in vehicle- and in L-NAME-injected rats.

Treatment with L-NAME led to a significant decrease of basal values for PRA from $8 \pm 1.2 \mathrm{ng}$ ANGI $\cdot \mathrm{h}^{-1} \cdot \mathrm{ml}^{-1} \quad($ mean $\pm \mathrm{SEM} ; n=6)$ to 2.8 $\pm 0.65 \mathrm{ng}$ ANGI $\cdot \mathrm{h}^{-1} \cdot \mathrm{ml}^{-1}(n=6)$ (Fig. 4). Clipping of the left renal arteries for 2 days increased PRA values to $35 \pm 5.4 \mathrm{ng}$ ANGI $\cdot \mathrm{h}^{-1} \cdot \mathrm{ml}^{-1}(n=6)$ in vehicle-injected rats, and to $13 \pm 3.6 \mathrm{ng}$ ANGI $\cdot \mathrm{h}^{-1} \cdot \mathrm{ml}^{-1}(n=$

6) in L-NAME-treated animals (Fig. 4).

Renin m-RNA levels in the kidneys and in the adrenal glands were analysed by RNase protection. RNase protection assays for renin m-RNA on total RNA were performed using a 296-bp antisense riboprobe of rat preprorenin m-RNA. Figure 5 (upper panel) shows a representative autoradiograph of such an RNase protection assay for the left and right kidneys isolated from nonclipped vehicle-injected, nonclipped L-NAME-treated, left-side clipped vehicle-injected and left-side clipped LNAME-treated rats. For comparison and quantification $20 \mu \mathrm{g}$ of an aliquot from a pool of total RNA isolated from 12 kidneys of 6 normal adult male rats was coanalysed on the gel as an external standard (St). It is evident from Fig. 5 that renin m-RNA was decreased in the kidneys from the L-NAME-treated nonclipped rat when compared with the nonclipped vehicle-injected animal. Left renal artery clipping led to a marked increase of renin $\mathrm{m}$-RNA in the clipped kidney and to a suppression of renin $\mathrm{m}-\mathrm{RNA}$ in the contralateral kidney in vehicle-

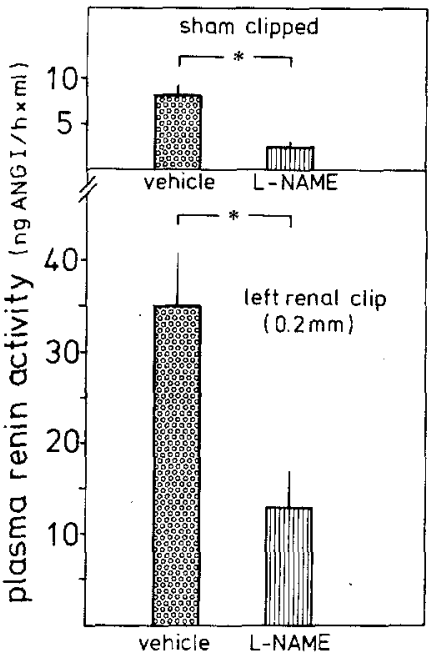

Fig. 4. Upper panel shows PRA of sham-clipped vehicle-injected and sham-clipped L-NAME-(40 mg/kg, twice a day)-injected rats after $48 \mathrm{~h}$. PRA is expressed as ng angiotensin I (ANGI)/h $\times \mathrm{ml}$. Lower panel shows PRA of clipped, vehicle-injected and clipped L-NAME-(40 mg/kg, twice a day)-injected rats after $48 \mathrm{~h}$. Data are means $\pm S E M$ of 6 animals in each experimental group. $* P<0.05$

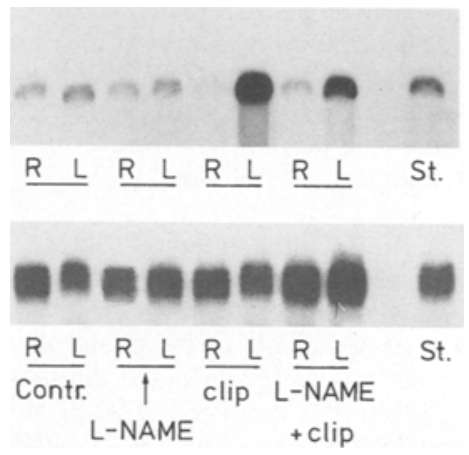

Fig. 5. Upper panel shows an autoradiograph of RNase protection assay for renin m-RNA with total renal RNA isolated from vehicle-injected, sham-clipped (contr.), L-NAME-injected, shamclipped ( $L-N A M E)$ vehicle-injected clipped (clip), L-NAME-injected, clipped ( $L-N A M E+$ clip) rats. $20 \mu \mathrm{g}$ of total RNA were analysed in each assay. $R$, Right (contralateral) kidney; $L$, left (clipped) kidney; St, $20 \mu \mathrm{g}$ of RNA standard. Lower panel shows the corresponding autoradiograph of RNase protection assay for $\beta$-actin m-RNA. $2.5 \mu \mathrm{g}$ of total RNA are analysed in each assay. $S t, 2.5 \mu \mathrm{g}$ of RNA standard

injected rats. In the L-NAME-treated animals the increases and suppression of renin m-RNA levels in the ipsilateral and contralateral kidneys, respectively, were markedly attenuated. For further quantification, protected fragments were excised from the dried gels and measured by assessing the $\beta$ radioactivity. After background subtraction the radioactivity of each band was related to that of the external standard RNA and expressed as a percentage of the standard. Average renin m-RNA levels that were quantified in this way for left and right kidneys isolated from the rats of the four experimental groups are summarized in Fig. 6. In nonclipped animals there was no systematic side difference 


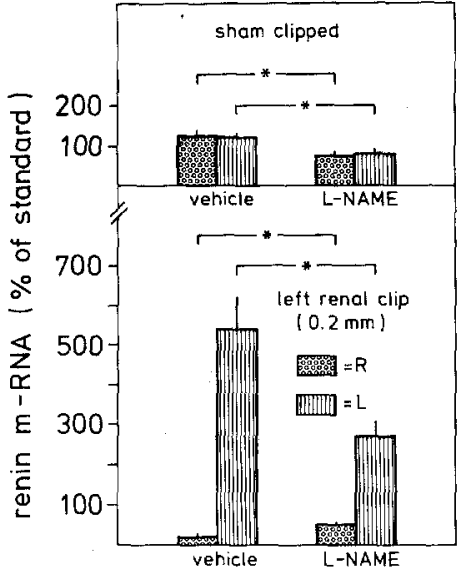

Fig. 6. Upper panel shows renal renin m-RNA levels expressed in relation to an external standard in sham-clipped rats injected with vehicle $(0.9 \% \mathrm{NaCl})$ or with L-NAME $(40 \mathrm{mg} / \mathrm{kg})$ twice a day for $48 \mathrm{~h}$. Lower panel shows renal renin m-RNA levels expressed in relation to an external standard in rats with a left renal artery clip $(0.2 \mathrm{~mm})$ and injected with vehicle $(0.9 \% \mathrm{NaCl})$ or with L-NAME ( $40 \mathrm{mg} / \mathrm{kg}$ ) twice a day for $48 \mathrm{~h}$. $R$, Right (contralateral) kidney; $L$, left (clipped) kidney. Data are means \pm SEM of 6 animals in each experimental group. $* P<0.05$

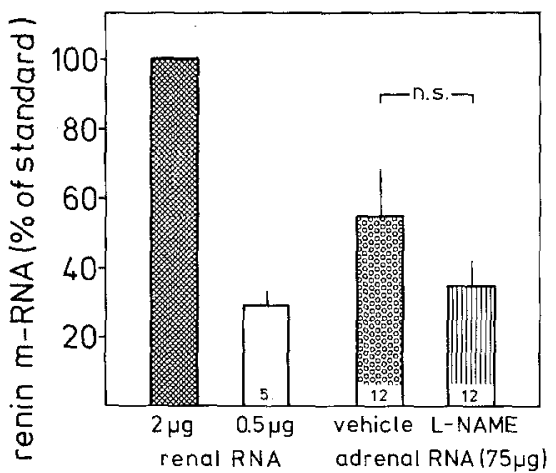

Fig. 7. Effect of L-NAME ( $40 \mathrm{mg} / \mathrm{kg}$, twice a day) on adrenal renin m-RNA levels expressed in relation to an external standard $(2 \mu \mathrm{g}$ of total RNA from control animals). Data are means \pm SEM. Number of animals is indicated in the bottom of bars

of renin m-RNA levels between the two kidneys and LNAME treatment led to a $35 \%$ decrease of basal renin m-RNA levels (Fig. 6, upper panel). In vehicle-injected rats clipping of the left renal artery with a $0.2-\mathrm{mm}$ clip increased renin m-RNA levels by $450 \%$ over the basal level in the clipped kidney and decreased m-RNA levels to $16 \%$ of the basal level in the contralateral right kidneys (Fig. 6, lower panel). In L-NAME-treated animals renin $\mathrm{m}-\mathrm{RNA}$ levels in the clipped kidney rose by $220 \%$ over the basal value of vehicle-injected rats and renin m-RNA levels in the contralateral kidneys decreased to $50 \%$ of the basal value. For control we also analysed the expression of a house-keeping gene such as $\beta$-actin in vehicle- and L-NAME-treated rats. As illustrated in Fig. 5 (lower panel) there was no consistent difference in the abundance of actin m-RNA in total RNA isolated from the kidneys of the animals of the four experimental groups.

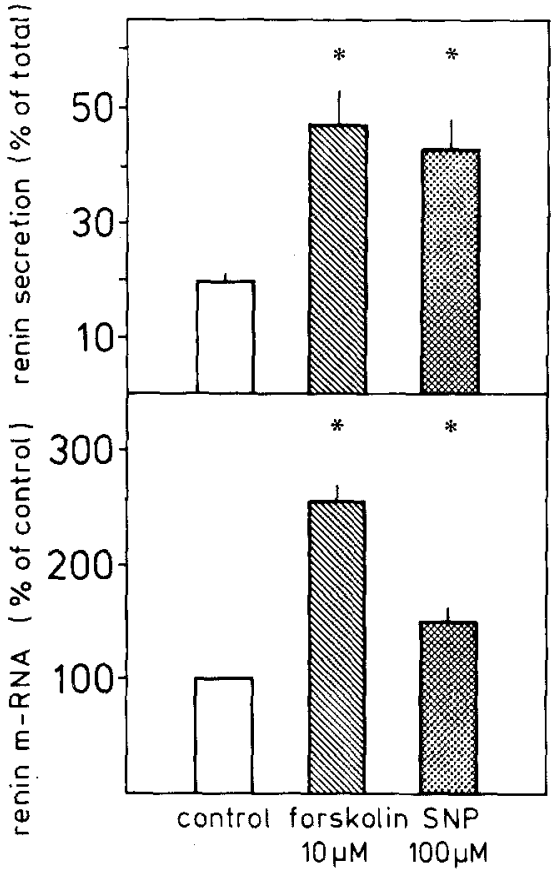

Fig. 8. Upper panel shows the effect of forskolin $(10 \mu \mathrm{M})$ and of sodium nitroprusside $(S N P, 100 \mu \mathrm{M})$ on $20 \mathrm{~h}$ renin secretion from cultured mouse renal juxtaglomerular ( $\mathrm{JG}$ ) cells. Renin secretion is expressed as the percentage of the total renin activity present in the cultures. Data are means \pm SEM of 8 experiments done with different cell preparations. Each experiment represents the mean of quadruplicate culture wells. Lower panel shows the effect of forskolin $(10 \mu \mathrm{M})$ and of SNP $(100 \mu \mathrm{M})$ on renin m-RNA levels in the primary cultures of mouse renal JG cells. Data are means \pm SEM of 8 different culture preparations. To minimize differences among different cell culture preparations, renin m-RNA levels in the presence of forskolin and of SNP are expressed as a percentage of the renin $\mathrm{m}$-RNA found in the cultures treated with vehicle only

Besides the kidney, the adrenal gland has been recognized also as a relevant site of renin gene expression. We therefore analysed renin m-RNA levels in total RNA isolated from the adrenal glands of the L-NAME-treated and of vehicle-injected rats. Because of the rather low abundance of renin m-RNA in total RNA isolated from adrenal glands the long exposure time of the autoradiograph did not allow quantification of the protected fragments by assessing the $\beta$ radioactivity. Therefore the bands on the autoradiograph were analysed by laser densitometry and the values obtained were given as a proportion of that obtained with $2 \mu \mathrm{g}$ of the renal standard RNA which was coanalysed on each gel. To acertain linearity of densitometric evaluation, $0.5 \mu \mathrm{g}$ of standard RNA were also coanalysed and given as a proportion of $2 \mu \mathrm{g}$ of standard RNA (Fig. 7). Adrenal renin m-RNA levels analysed by this way displayed a rather broad variance when compared with renal renin $m$-RNA levels. In sham-clipped vehicle-injected rats the abundance of renin $\mathrm{m}$-RNA in adrenal glands was on average $2 \%$ of the value found for the kidneys. By ANOVA we found no difference of adrenal renin m-RNA levels between sham-clipped and clipped rats neither during vehicle nor during L-NAME injection. To examine the overall effect 
of L-NAME treatment on adrenal renin gene expression, therefore, we pooled the data for sham-clipped and clipped animals in both the vehicle and the L-NAME groups. As shown in Fig. 7 there was a tendency towards lower adrenal renin m-RNA levels in L-NAME-treated rats when compared with vehicle-injected animals. This difference, however, did not reach the level of statistical significance $(P>0.05)$.

The results described so far have not allowed distinction between direct and indirect effects of EDNO on renin secretion and renin gene expression. Therefore, we attempted to examine possible direct effects by examining the influence of the NO-donor nitroprusside on isolated renal JG cells. To this end, primary cultures of mouse renal JG cells were incubated with sodium nitroprusside (SNP, $100 \mu \mathrm{M}$ ) for $20 \mathrm{~h}$ and renin secretion was measured and cellular renin m-RNA levels were determined by RT-PCR as described recently [5]. For comparison we also examined the effects of the adenylate cyclase activator forskolin $(10 \mu \mathrm{M})$, which has recently been shown to stimulate renin secretion and renin gene expression in isolated JG cells [5]. As shown in Fig. 8 (upper panel) SNP and forskolin produced comparable increases of renin secretion. Both drugs also led to significant $(P<0.01)$ increases of cellular renin $\mathrm{m}$-RNA levels, with the difference that forskolin was more potent than SNP (Fig. 8, lower panel). For control we also measured total RNA synthesis in the cultured cells by pulse experiments with $\left[{ }^{3} \mathrm{H}\right]$ uridine. In these experiments we found no effect of $100 \mu \mathrm{M}$ SNP or $10 \mu \mathrm{M}$ forskolin on total RNA synthesis.

\section{Discussion}

It was the aim of this study to examine the effect of EDNO on renin gene expression in the kidney under both basal conditions and under stimulation by a reduction of renal perfusion induced by unilateral $0.2-\mathrm{mm}$ artery clips. In the presence of left renal artery clips renin m-RNA levels increased transiently in the clipped kidney with a time course which was similar to the timedependent changes of renin secretion found in experimental Goldblatt-hypertension [6]. In parallel, renin $\mathrm{m}-$ RNA levels were constantly suppressed in the contralateral kidney. Similar temporal patterns of renal renin m-RNA levels have already been described for unilateral renal artery clipping [12] and for aortic coarctation [13].

Inhibition of endogenous EDNO formation was achieved with intraperitoneal injections of L-NAME, a well-established inhibitor of NO-synthase in vivo [22]. We found that administration of L-NAME to the conscious rats significantly decreased PRA and renal renin m-RNA levels under basal conditions, suggesting inhibition of basal renin secretion and of basal renal renin gene expression by L-NAME. Inhibition of endogenous EDNO formation has been reported to increase blood pressure [22] and to decrease heart rate [22], which could suggest a reflex inhibition of sympathetic activity. Both reactions could in principle lead to a decrease of renin secretion and of renin gene expression, because blood pressure and renal nerve activity have been found to be activators of renin secretion and of renin gene expression $[6,12,17,29]$. In our experiments we did not observe an effect of L-NAME on heart rate, which we considered as an indirect measure for sympathetic activity. Systolic blood pressure, however, increased significantly during treatment with L-NAME and, therefore, we can not definitively exclude the possibility from our experiments that the effects of L-NAME on basal PRA and on basal renal renin m-RNA levels were mediated by an increase of blood pressure. Changes of blood pressure or of sympathetic activity, however, are rather unlikely to account for the attenuation of renin secretion rates and renal renin m-RNA levels in animals with unilateral renal artery clips, because in those animals there were no differences in heart rates and in systolic blood pressures between the vehicle- and the L-NAME-treated animals. We infer, therefore, that the effects of L-NAME on the renin system in $2 \mathrm{~K}-1 \mathrm{C}$ rats were primarily due to inhibition of intrarenal EDNO formation, rather than indirectly mediated by a side effect. This conclusion is supported by the previous findings that inhibitors of EDNO formation attenuate renal renin secretion in vitro in isolated perfused rat kidneys $[8,15,23]$ and in cocultures of renal JG and endothelial cells [11], as well as in vivo in dogs upon systemic and intrarenal application $[16,18]$. Conversely, our findings now show that EDNO is a stimulator of renin secretion and of renin gene expression in renal JG cells (Fig. 8). Thus, it appears likely that the in vivo effects of L-NAME are at least in part related to a direct stimulatory effect of EDNO on renal JG cells. In vivo experiments and experiments with isolated perfused rat kidneys have, moreover, produced evidence that the stimulation of renin secretion upon lowering the perfusion pressure is particularly sensitive to inhibition of endogenous EDNO production $[18,23]$. Our data do confirm this notion and now provide the first evidence that the same holds for renin gene expression in the hypoperfused kidney. Thus, EDNO appears to be an activator of renal renin gene expression, and is involved in the control of the renin gene via the perfusion pressure. In this study we found that L-NAME attenuated the increases of renal m-RNA levels and of renin secretion in $2 \mathrm{~K}-1 \mathrm{C}$ animals by about $50 \%$. This value is close to the inhibition by L-NAME of renin release stimulated by low renal artery pressure in conscious dogs [18]. Intrarenal application of NO-synthase inhibitors in anaesthetized dogs [16], or in isolated perfused kidneys, [23] has been found to decrease the renin secretion response to low perfusion pressure by $70-$ $80 \%$. It is not unlikely, therefore, in our experiments with conscious rats that EDNO production was not completely blocked, raising the possibility that a more effective inhibition of the NO system would further decrease renin gene expression in response to hypoperfusion of the kidney.

Interestingly, renin m-RNA levels in the contralaterals as opposed to the stenosed kidneys in L-NAMEtreated animals were not as strongly suppressed as in vehicle-injected rats. This may indicate that there was a minor release of factors that cause suppression of renin 
gene expression in contralaterals as opposed to stenosed kidneys. Although these factors have not yet been unequivocally characterized, angiotensin II (ANGII) is considered to be a likely candidate [20]. Our findings would not disagree with this concept, since L-NAME markedly suppressed renin secretion rates and thus the formation of systemic ANGII in the $2 \mathrm{~K}-1 \mathrm{C}$ animals.

Besides the kidneys, the adrenal glands also have been recognized as a relevant site of renin gene expression. Moreover, it has been found recently that both renal and adrenal renin gene expression are stimulated by low salt intake $[7,10]$, suggesting that adrenal and renal renin gene expression can in principle be regulated by common factors. This was the reason for us to also consider a possible influence of EDNO on adrenal renin gene expression. Indeed there was a tendency of adrenal renin m-RNA levels to decrease during L-NAME treatment, suggesting that EDNO might also be a stimulator of renin gene expression in adrenal glands. With 12 animals in each group, however, this effect did not reach statistical significance. It should be recalled in this context that the inhibitory effect of L-NAME on renal renin gene expression was also moderate under basal conditions and was more pronounced during stimulation by unilateral renal artery clipping, a manoeuvre which in turn had no effect on adrenal renin gene expression.

The question arises whether the stimulatory effect of EDNO on renin gene expression is like the effect of cAMP, a direct effect or one that is secondary to the stimulation of renin secretion by EDNO. In fact several possible modes of interdependent and independent controls of renin secretion and of renin synthesis have been previously reviewed [25]. Due to the poor understanding of the control of the renin gene on the level of JG cells, however, all of these models await further confirmation. Recently, we have found that in primary cultures of mouse renal JG cells the secretion and the synthesis of renin are not strictly linked [4], suggesting that renin secretion and renin gene expression might be independently regulated from each other. In this view our present findings would suggest that EDNO is an activator of renin secretion and of renin gene expression in vitro and in vivo, which appears to be involved importantly in the control of renin gene expression by the renal perfusion pressure. A direct stimulatory effect of EDNO on transcriptional activity was in fact recently demonstrated for PC12 cells [19]. To examine the mechanisms along which EDNO could activate renin gene expression on the level of JG cells will be a task for our future work.

Acknowledgements. We thank R. Metzger, Heidelberg, Germany, for providing us with the rat preprorenin cDNA and P. Ratcliffe, Oxford, UK, for providing us with rat $\beta$-actin cDNA. The expert technical and graphical assistance provided by K. H. Götz, M. L. Schweiger and the secretarial help provided by $\mathbf{H}$. Trommer is gratefully acknowledged. This study was financially supported by a grant from the Deutsche Forschungsgemeinschaft Ku 859/2-1.

\section{References}

1. Beierwaltes WH, Carretero OA (1992) Nonprostanoid endothelium-derived factors inhibit renin release. Hypertension [Suppl II] :68-73
2. Burnham CE, Hawelu-Johnson CL, Frank BM, Lynch KR (1987) Molecular cloning of rat renin cDNA and its gene. Proc Natl Acad Sci USA 84:5605-5609

3. Chomczynski P, Sacchi N (1987) Single-step method of RNA isolation by acid guanidinium thiocyanate-phenol-chloroform extraction. Anal Biochem 162:156-159

4. Della Bruna R, Pinet F, Corvol P, Kurtz A (1991) Regulation of renin secretion and renin synthesis by second messengers in isolated mouse juxtaglomerular cells. Cell Physiol Biochem $1: 98-110$

5. Della Bruna R, Kurtz A, Corvol P, Pinet F (1993) Renin mRNA quantification using polymerase chain reaction in cultured juxtaglomerular cells. Circ Res 73:639-649

6. Dzau VJ, Siwek LG, Barger AC (1981) In: Laragh JH, Buhler FR, Seldin DW (eds) Frontiers in hypertension research. Intracellular resistance in experimental benign and malignant hypertension. Springer, Berlin Heidelberg New York, pp 165168

7. Dzau VJ, Brody T, Ellison KE, Pratt RE, Ingelfinger JR (1987) Tissue-specific regulation of renin expression in the mouse. Hypertension [Suppl III] : 36-41

8. Gardes J, Poux JM, Gonzales MF, Alhenc-Gelas F, Menard J (1992) Decreased renin release and constant kallikrein secretion after injection of L-NAME in isolated perfused rat kidney. Life Sci 50:987-993

9. Hackenthal E, Paul M, Ganten D, Taugner R (1990) Morphology, physiology and molecular biology of renin secretion. Physiol Rev 70:1067-1116

10. Imwai N, Inagami T (1992) Quantitative analysis of renin gene expression in extrarenal tissues by polymerase chain reaction method. J Hypertens 10:717-724

11. Kurtz A, Kaissling B, Busse R, Baier W (1991) Endothelial cells modulate renin secretion from isolated mouse juxtaglomerular cells. J Clin Invest 88:1147-1154

12. Makrides SC, Mulinari R, Zannis VI, Gavras H (1988) Regulation of renin gene expression in hypertensive rats. Hypertension $12: 405-410$

13. Moffett RB, McGowan RA, Gross KW (1986) Modulation of kidney renin messenger RNA levels during experimentally induced hypertension. Hypertension 8:874-882

14. Mundel P, Bachmann S, Bader M, Fischer A, Mayer B, Kriz W (1992) Expression of nitric oxide synthase in the kidney macula densa cells. Kidney Int 42:1017-1019

15. Münter K, Hackenthal E (1991) The participation of the endothelium in the control of renin release. $J$ Hypertension 9 [Suppl 6]: 236-237

16. Naess PA, Christensen G, Krikeboen KA, Kill F (1993) Effect on renin release of inhibiting renal nitric oxide synthesis in anaesthetized dogs. Acta Physiol Scand 148:137-142

17. Osborn JL, DiBona GF, Thames MD (1981) Beta-1 receptor mediation of renin secretion elicited by low frequency renal nerve stimulation. J Pharmacol Exp Ther 216:265-269

18. Persson PB, Baumann JE, Ehmke H, Hackenthal E, Kirchheim H, Nafz B (1993) Endothelium derived NO stimulates pressure dependent renin release in conscious dogs. Am $\mathrm{J}$ Physiol 264:F943-F947

19. Peunova N, Enikolopov G (1993) Amplification of calciuminduced gene transcription by nitric oxide in neuronal cells. Nature 364:450-453

20. Ploth DW (1983) Angiotensin-dependent renal mechanisms in two-kidney one-clip renal vascular hypertension. Am J Physiol 245:F131-F141

21. Ratcliffe PJ, Jones RW, Philips RE, Nicholls LG, Bell JI (1991) Oxygen-dependent modulation of erythropoietin mRNA levels. J Exp Med 172:657-660

22. Rees DD, Palmer RMJ, Schulz R, Hodson RF, Moncada S (1990) Characterization of three inhibitors of endothelial nitric oxide synthase in vitro and in vivo. Br J Pharmacol 101 : 746752 
23. Scholz H, Kurtz A (1993) Endothelium derived relaxing factor is involved in the pressure control of renin secretion from the kidneys. J Clin Invest $91: 1088-1091$

24. Sigmon D, Carretero OA, Beierwaltes W (1992) Endotheliumderived relaxing factor regulates renin release in vivo. Am J Physiol 263:F256-F261

25. Taugner R, Hackenthal E (1989) The juxtaglomerular apparatus. Springer, Berlin Heidelberg New York

26. Thorup C, Sundler F, Ekblad E, Persson AEG (1993) Resetting of tubuloglomerular feedback mechanism by blockade of NO-synthesis. Acta Physiol Scand 148:359-360
27. Vidal MJ, Romero JC, Vanhoutte PM (1988) Endotheliumderived relaxing factor inhibits renin release. Eur J Pharmacol $149: 401-402$

28. Wilcox CS, Welch WJ, Murad F, Gross SS, Taylor G, Levi R, Schmidt HHHW (1992) Nitric oxide synthase in macula densa regulates glomerular capillary pressure. Proc Natl Acad Sci USA 89:11 993-11 997

29. Zhang Y, Morgan T, Read G (1992) The role of the renal nerves in renin synthesis. Clin Exp Pharmacol Physiol $19: 827-831$ 